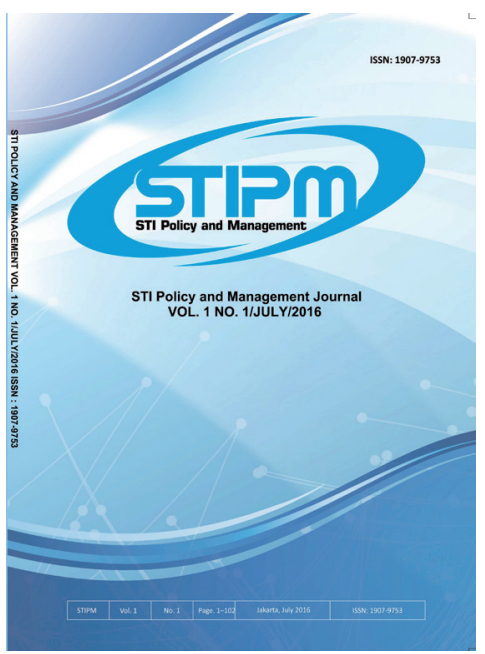

Journal of STI Policy and Management

Publication details, including instructions for authors and subscription information: http://www.stipmjournal.org/

\title{
Technological Capability Upgrading and Entrepreneurship: Case Study of Selected Indonesian Fish Processing Companies
}

Erman Aminullah, Trina Fizzanty, Galuh S. Indraprahasta, and Indri J. Asmara

Center for Science and Technology Development Studies, Building A, PDII LIPI, Jakarta 12710, Indonesia

Version of record first published: 15 July 2016

To cite this article: Aminullah E., Fizzanty, T., Indraprahasta, G.S., \& Asmara, I.J. (2016). Technological Capability Upgrading and Entrepreneurship: Case Study of Selected Indonesian Fish Processing Companies. Journal of STI Policy and Management, 1(1), 41-57

To link to this article: http://dx.doi.org/10.14203/stipm.vli1

ISSN 1907-9753 (Print); ISSN 2502-5996 (online)

Accreditation Number: 622/AU3/P2MI-LIPI/03/2015

Full terms and conditions of use: https://creativecommons.org/licenses/by-nc-sa/4.0/

You are free to:

- Share : copy and redistribute the material in any medium or format

- Adapt : remix, transform, and build upon the material

- The licensor cannot revoke these freedoms as long as you follow the license terms.

Under the following terms:

Attribution - You must give appropriate credit, provide a link to the license, and indicate if changes were made. You may do so in any reasonable manner, but not in any way that suggests the licensor endorses you or your use.

NonCommercial - You may not use the material for commercial purposes.

ShareAlike - If you remix, transform, or build upon the material, you must distribute your contributions under the same license as the original.

No additional restrictions - You may not apply legal terms or technological measures that legally restrict others from doing anything the license permits.

Notices:

- You do not have to comply with the license for elements of the material in the public domain or where your use is permitted by an applicable exception or limitation.

- No warranties are given. The license may not give you all of the permissions necessary for your intended use. For example, other rights such as publicity, privacy, or moral rights may limit how you use the material.

- If you copy the dataset merely to extract the uncopyrightable data elements would not need permission to do so. However, if you republish the full dataset or using the copyrightable data layers require a permission from PAPPIPTEK-LIPI. 


\section{JOURNAL OF STI POLICY AND MANAGEMENT}

Volume 1 No. 1 July 2016

\section{LIST OF CONTENTS}

Innovation System Reform in Indonesia and Vietnam: A new Role for Universities?

Erik Baark.

Technology and Standardization Strategies related to the Diffusion of Smart Houses: The Case of ECHONET in Japan

Kumiko Miyazaki, Kentaro Nishida

Intellectual Property Creation of Japanese Companies in China and Thailand

Masayuki Kondo.

Technological Capability Upgrading and Entrepreneurship: Case Study of Selected Indonesian Fish Processing Companies

Erman Aminullah, Trina Fizzanty, Galuh S. Indraprahasta, and Indri J. Asmara

Influential Factors of Evidence-Based Energy Policy-making: Government Regulation on Targeting Renewable Energy in Indonesia

Wati Hermawati, Prakoso Bhairawa Putera, Dudi Hidayat, and Ishelina Rosaira P.

Finding the Most Efficient Technology Transfer Route Using Dijkstra Algorithm to Foster Innovation: The Case of Essential Oil Developments in the Research Center for Chemistry at the Indonesian Institute of Sciences

Arief A. R. Setiawan, Anny Sulaswatty, and Agus Haryono 


\section{Technological Capability Upgrading and Entrepreneurship: Case Study of Selected Indonesian Fish Processing Companies}

Erman Aminullah, Trina Fizzanty, Galuh S. Indraprahasta, Indri J. Asmara

Center for Science and Technology Development Studies, Building A, PDII LIPI, Jakarta 12710, Indonesia

\begin{tabular}{l}
\hline ARTICLE INFO \\
\hline Article History: \\
Received : 25 January 2016 \\
Revised : 29 April 2016 \\
Accepted : 26 May 2016 \\
Available online : 15 July 2016 \\
\hline
\end{tabular}

Keywords:

Entrepreneurship

Fish processing industry

Innovation modes

Sectoral Innovation System

Technological upgrading

\begin{abstract}
This study analyzes the technological capability upgrading and entrepreneurship in the Indonesian fish processing industry. The analysis viewed from the Sectoral Innovation System (SIS) focuses on two aspects: the enabling factors for innovation, and the role of entrepreneur in technological capability upgrading. The study finds that Indonesian fish processing companies: (i) are less interactive with local universities or other STI (science, technology and innovation) centers, and innovation was mostly done through learning by DUI (doing, using and interacting); (ii) are characterized as low-tech industries with a high standard for food safety and product differentiation; (iii) apply adaptive innovation, modified from existing technology or knowledge, except for the leading companies who apply innovation for new products in the market; (iv) actors, technology, market trends, and networks are the main enabling factors for innovation; and (v) the role of entrepreneurs - especially in building entrepreneurial networks - were dominant in the leading companies. The entrepreneurial networks exist and work in global distribution chains that are widely adopted by companies to export their products through buyer-producer relationships. The pathways toward export markets are: global born directly, fastly learned global, and delay learned global companies. These categories have enriched the Mets category (2012). The policy implications of the findings for government should: (i) facilitate companies' interaction with local universities or other STI centers; and (ii) encourage domestic companies to improve their competitiveness by shifting to higher added value products through various innovations and trading policy schemes.
\end{abstract}

\footnotetext{
* Corresponding Author.

E-mail: aminullahe@yahoo.com
} 


\section{INTRODUCTION}

\section{A. Background and objective}

As the largest archipelagic country in the world, Indonesia possesses natural comparative advantages in its fish processing industry. Fish processing in Indonesia largely utilizes domestic marine production to produce diversified fish products from tuna, shrimp, seaweed, and others. There are three major fish processing product categories, namely: frozen fish, canned fish, and fish meal. While the fish processing industry occupies an important position in Indonesia and its contribution (in nominal value) to the Indonesian GDP (Gross Domestic Product) that has continued to increase, its contribution (in percentage terms) was less than one percent and has tended to decrease slightly recently (see Appendix 1).

The problems faced by the Indonesian fish processing industry generally relate to the quality of fish and the added value from processing. The low quality of fish is caused by careless handling, poor sanitation, and inferior port facilities. A study by Duijn van (2012) identified six problems related to Indonesian fish products for export markets: (i) poor handling and cold storage of the fish after catching due to lack of skill and knowledge; (ii) failure to comply with the traceability requirements (i.e. EU catch certificates) due to lack of equipment to record the catching of fish and fishing areas; (iii) difficulty in complying with the requirements for eco-labeling of fish products for export markets; (iv) trade barriers on exporting tuna to the EU; (v) lack of capacity for small/medium processors to conduct market intelligence about the relevant export markets; and (vi) fluctuating fish catches due to declining fish stocks affecting the supply of fish for the processing industry. Meanwhile, the demand for fish is increasing due to the variety of products that require a greater supply of fish.

Given the complexity of problems faced by the Indonesian fish processing industry, both aspects, the crisis of supply and the increasing demand for product variation, have forced the fish processing industry to spur creativity and innovation. Previous research about innovation in Indonesian fish commodities and products have found that: (i) increases in productivity of seafood (shrimp) are associated with a research budget for shrimp, providing seed quality, and human resource capacity-building (Juarno, 2011); (ii) export competitiveness of Indonesian fishery products is still weak regarding the processing of added-value products (Saptanto, 2011); (iii) research results play an important role as input for decision-making on policy surrounding fisheries in Indonesia (Asmara, 2012). Other related studies on innovation in the seafood industry cover: (i) the innovation and quota management system (Jeffs, n.d.); (ii) governance of the industrial policy and innovation system (Aslesen, 1999); and (iii) production changes and innovation systems (Gonzalez-Lopez, 2012). This study focuses on technological upgrading and entrepreneurship in the Indonesian fish processing companies. It contributes toward the scientific knowledge base built by existing studies on innovation in the Indonesian fish processing industry.

This study analyzes the technological capability upgrading and innovation activities and the modes of innovation and entrepreneurial networks by fish processing companies. The focus of analysis emphasizes on answering these questions: (i) How does the interactive learning process by the interaction of various actors (individual and organization) in products, processes, and service innovation take place inside companies? (ii) What are the enabling factors for innovation inside companies viewed from the SIS perspective? (iii) How do innovative entrepreneurs implement their innovation activities in companies? (iv) How do companies implement the learning process to become global market players?

\section{B. Methodology}

This study uses the case study method. The case studies were conducted in selected companies matching the following criteria: (i) companies that operate in the same field as the fish processing industry; (ii) companies that have global distribution or export markets; and (iii) companies that represent medium- and large-scale companies for each case study.

The content of the information collected from the informants was related to: (i) the generic 
features of each company viewed from various aspects; (ii) the improvement of capabilities made by the company; (iii) the company's network of suppliers and customers both in the domestic and global markets; and (iv) entrepreneurship, including the advantages created by the company and the sources of innovative ideas that ensure the company's advantage. The information was obtained from various sources such as in-depth personal interviews, observation of online data and relevant publications. The detailed observation was undertaken during a field visit inside the company. All interviews were recorded and transcribed.

The analysis and interpretation of data from the case study involved iteration between empirical evidence and theoretical perspective. The data analysis was carried out in two phases, the first being individual case study analysis that described each company's case and then crosscase analysis that attempted to find any cross relationships within the findings. The analysis of data included the processes of categorization, abstraction, comparison, and integration. In order to ensure the quality of the case study findings, the standard procedures for qualitative research were applied.

The results of each case study were prepared in the following format: (i) Introduction; (ii) Sectoral innovation system of the Indonesian fish processing industry; (iii) Case study findings consisting of the company's business evolution, technological capability upgrading, modes of innovation, and the role played by entrepreneurs for technology upgrading; (iv) Analyzing the crosscases study findings by comparing the similarities and differences among the three cases to draw lesson learned; and (v) Conclusion.

\section{THE SECTORAL INNOVATION SYSTEM (SIS)}

\section{A. The Sectoral Innovation System}

This study uses the concept of sectoral innovation (SIS) as a lens to understand how innovation occurs at the company/sector level as a system; that is, from the perspective of innovation as an interactive learning system by a set of agents that carry out interactions through networks, which are determined by the institution. (Malerba, 2002, 2009). Effective learning can use both internal sources of knowledge (R\&D units, production, and marketing) and external sources of knowledge (universities, research institution, suppliers and users). Further, learning differs according to the mode; knowledge can be acquired through either DUI (doing, using and interacting) or STI modes (R\&D activities, scientific advancement and technology spillover).

The set of agents interacting through networks describe the various ways in which the actors are connected in the system. The actors as agents of the system are categorized as either individual or organization actors. Individual actors include consumers, businessmen, and scientists. Organization actors include firms with their internal units (i.e. R\&D, production, and marketing) and external organs (i.e. users, suppliers, universities, research institutions, financial institutions, government agencies, business associations, and business principals). The networks provide various paths for accessing knowledge and technology in the system. The variations of access are characterized by market and non-market relationships. Furthermore, demand is generated by a set of agents that interacts with producers. These agents include consumers, corporations, and the government sector. The interaction of agents with producers is formed and influenced by both market and non-market institutions. Demand functions as a pull factor for innovation, especially innovation for solving the problem of demand, i.e. innovation based on input from users and suppliers.

The interaction of agents in the system is determined by the institutions that arise through binding and non-binding agreements. There are market institutions such as monopolies, oligopolies, and competition. Meanwhile, non-market institutions comprise sociopolitical factors, i.e. political guidance and sectoral shifts of national planning and policy directed by the domestic agencies. Institutions can explain the specific way a sector or firm organizes its innovative activities in accordance with formal contracts and informal 
arrangements as well as market and non-market institutions.

\section{B. Role of the actors and entrepreneurial networks in the SIS}

In the SIS, the actors and entrepreneurial networks play roles in integrating and configuring individual resource capabilities into an organizational capability inside the system. The entrepreneur's role is to spur industrial growth and progress. Any variation in the growth of firms at both company and industrial level can be explained in part by an entrepreneur's decisions to stimulate the knowledge flow, both through learning by DUI and $R \& D$ activities (intramural and extramural) that lead to knowledge accumulation. The role of the entrepreneur is also important as the driver for their company to learn, shift, and grow its global business. There are three pathways to global business: (i) learned global, where a company is led to global business slowly by learning from experience and accumulating knowledge; (ii) global-born, integration into a global business in a short time as the company was founded with the concept to operate globally; and (iii) born-again global, a domestic company that suddenly goes global after a shock or when triggered by critical events (Mets, 2012).

Entrepreneurs focus on risk-taking, proaction, innovation as well as clear orientation and a specific capability. The specific capability of an entrepreneur is a constant alertness to new international market opportunities built up from the knowledge and learning acquired from earlier activities (Zucchella, 2007). Entrepreneurs build and maintain relevant, superior, and effective networks including social networks, which provide both information and trust in managing risk in a global business (Giusta, 2010). Entrepreneurial networks are vital for discovering opportunities, testing ideas, and garnering resources for the formation of new organizational structures (Weerawardena, 2007). Additionally, entrepreneurial networks exist and work in global distribution chains subject to the buyer-producer relationship (Nicita, Ogivtsev \& Shiratori, 2013).

\section{THE FISH PROCESSING INDUSTRY VIEWED FROM A SIS PERSPECTIVE}

The contribution of the fish processing industry to the Indonesian GDP has increased between 2007 and 2011. Nevertheless, the share of the fish processing industry within the Indonesian GDP is still limited and tended to stabilize during the above five-year period, from $2.75 \%$ in 2007 to $3.33 \%$ in 2011 . The fish processing industry employed 46,000 workers in 2007, increasing to 55,000 in 2011 . Fish processing production (mainly frozen fish and canned fish) increased from 692,000 tons in 2007 to 762,000 tons in 2011 (see Appendix 1).

Generally, the fish processing industry is supported by marine resources, which are a natural comparative advantage for Indonesia. The main commodities of the marine resources are tuna, skipjack tuna, and shrimp. Indonesia has become the largest tuna producer in the world since 2004, overtaking Japan. The production of tuna in the form of fresh, frozen, or preserved tuna is generally for the export market.

The fish processing industry is generally categorized as a low-tech industry and as already mature with limited activities of innovation. This categorization is still valid for the fish processing industry in Indonesia. In addition, innovation in this industry rarely takes place through formal $\mathrm{R} \& \mathrm{D}$, as more innovation happens through learning by DUI. Firstly, the fish processing industry learning by doing, by managing gradual improvement, such as improving the quality of fish based on knowledge and experience in handling and storing fish in the past. Secondly, the fish processing industry learning by using, by utilizing available modern technology to improve the efficiency of the production process and increase product quality. Thirdly, the fish processing industry learning by interacting by innovating inside a company after acquiring knowledge about new products through interaction with users, with suppliers of new equipment and cutting-edge technology, and with competitors, in order to enhance competitiveness.

The fish processing industry basically covers a very broad range of activities, from upstream 
to downstream activities. Innovation in the fish processing industry involves various factors. In general, there are three main groups of actors who deal with the fish processing industry in Indonesia, which are the government (both national and regional government), business actors represented by business associations, and universities and R\&D institutions. The Ministry of Marine Affairs and Fisheries (MMAF) and the Ministry of Industry (MI) are the main government actors implementing the industrialization of marine and fishery products (see Figure 1).

The role of universities and R\&D institutions is important in providing additional value, solutions, and technology for the industrial development of the fishery industry in Indonesia. The Bogor Agricultural University, University of Hasanuddin, and the Institute of Technology of 10 November have contributed to development of the fish processing industry. In addition to these universities, there are several public R\&D institutions which have a special unit for fishery and marine development, such as the Indonesian
Institute of Science (LIPI), the Agency for Technology Assessment and Application (BPPT), and the Agency for Fisheries Research and Development at the MMAF (Litbang KKP).

Another important factor involved in marine and fishery development is the business sector, represented by several associations. Their general aim is to increase their bargaining position with the government and with other business players. The associations could also be different depending on each region's characteristics and demand. For example, the Association for Fish Processing and Marketing Companies in Indonesia (AFPMCI) supports fishery-related activities, such as the provision of laboratories, packaging, retail sales, and certification issues. It also organizes seminars and provides information about the markets and applicable regulatory legislation. Further, the Association also supports the development of human resources and increasing member awareness regarding quality, quality improvement and product safety standards.

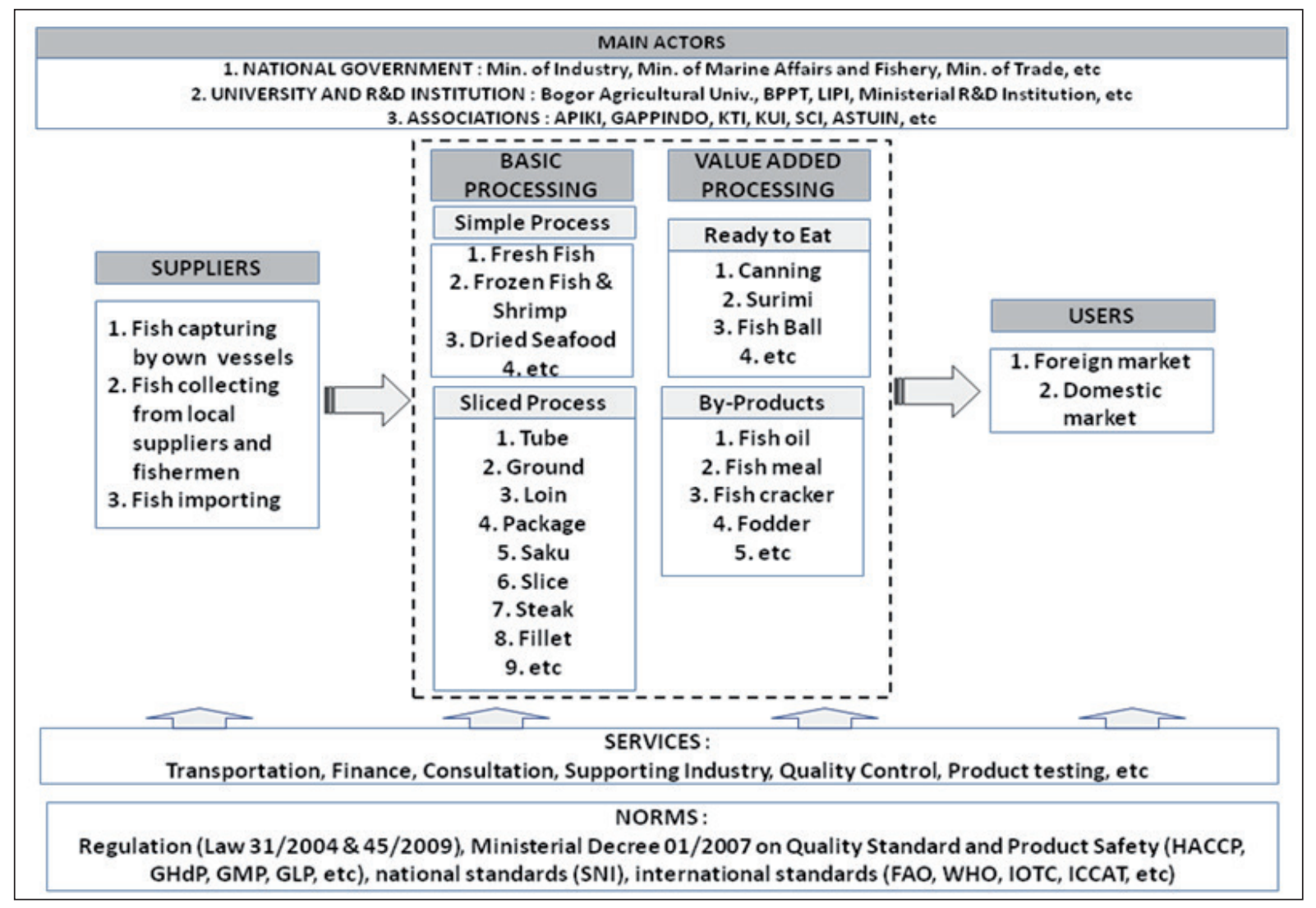

Figure 1. Sectoral innovation system of Indonesian fish processing industry 
The development of the fish processing industry is supported by several key regulations. Law 31/2004 on Fisheries-amended by Law 45/2009- functions as a policy umbrella for the fishery industry and its related activities. Structurally, the fishery industry in Indonesia is under the jurisdiction of two ministries, the Ministry of Marine Affairs and Fisheries (MMAF) and the Ministry of Industry (MI). The main regulations concerning the fishery industry are stipulated in the Ministerial Decree 27/2012 Regarding General Guidance on Fishery and Marine Industrialization, issued by the MMAF, and the Roadmap for the Processing Industry Development of Marine Products, issued by the MI.

The above decree also gives priority to the commodities and products to be developed, such as tuna-cob-skipjack, shrimp, bandeng, pindang (Indonesian semi-processed fish), patin (silver catfish), seaweed, and community salt. The Roadmap for the Processing Industry Development of Marine Products pays more attention to the processing substances and general roles of related actors. Based on the five-point International Standard Industrial Classification (ISIC), the fish processing industry is classified into five types: fish canning, fish salting and drying, fish smoking, fish freezing, fish pindang, and fish processing and preserving. Of these five types of industry, fish canning, fish freezing, and the seaweed processing industry are the core industries. These industries are supported by supporting industries, notably equipment suppliers, raw material suppliers, auxiliary material suppliers, and the shipping industry.

In order to satisfy the international market, the standard of fish products is absolutely essential. The MMAF Ministerial Decree 01/2007 on the Standard of Quality and Product Safety for Production, Processing, and Distribution Channels regulates the standard of quality for marine products. This standard of quality and product safety regulation applies to every process of the marine fishery business system, from fish catching to fish marketing. This decree regulates seven standards of quality and product safety that are required to be included in certain channel(s) of fishery activities, which are the HACCP (Hazard
Analysis Critical Control Point), GHdP (Good Handling Practices), GDP (Good Distribution Practices), SSOP (Standard Sanitation Operating Procedure), Pre-requisite Programs, GMP (Good Manufacturing Practices), and GLP (Good Laboratory Practices). In addition to the regulation of standards, there are several other standards for quality and safety, such as the SNI (the national standard of Indonesia) and Codex. The list of SNI standards indicates the minimum standard level for every product, process and method. Codex is the standard imposed by the FAO and WHO to provide harmonized food standards, guidelines, and codes of practice to protect the health of consumers and ensure fair practices in the food trade.

\section{TECHNOLOGICAL CAPABILITY UPGRADING IN FISH PROCESSING COMPANIES}

This section describes three cases of technological upgrading in fish processing companies. The focus is on: (i) company business evolution; (ii) technological capability upgrading as an interactive learning process; and (iii) the role of entrepreneurs in technology upgrading.

\section{Company A}

\section{a. The company's business evolution}

Company A was established in 1999 and is located in Jakarta's marine industrial complex. At present, the company is one of the leading frozen and fresh tuna producers in Indonesia and employs over 400 workers. The company produces various fresh and frozen fish products, which are mostly distributed to export markets.

The history of Company A can be traced back to its owner'sbusiness start in the early 1990s as a small fish trader in the Eastern Indonesian region. Between 1995 and 1996, the owner entered shrimp trading in collaboration with fishermen in the same region. To secure the supply, the company engaged with local fisherman through an interlocking collaboration, the so-called 'Plasma nucleus system'. Due to intense competition, in 
1996 the owner focused on tuna processing, but then similar problems occurred. The recurring instability of supply taught the company to not depend only on one commodity, but to expand into various seafood commodities; the company had diversified the business by the end of 1996. In 1999 , the company built a cold storage facility as well as bought fishing vessels and cargo vessels to support the business. In order to secure the plant and optimize storage in the event of any lack of supply, the company imported raw fish. Currently, the company is the largest Indonesian importer of salmon from Norway. Since 2011, the company has also become a food logistics company that provides modern logistical services including repacking, labelling, cargo services, and port documents.

\section{b. Technological capability upgrading}

The company began its operation using a conventional cold storage facility, butcontinually upgraded its technology through learning by interacting with technology suppliers. Currently, the company has an advanced warehouse system using robotic technology (automated and computerized). The firm has upgraded to the most efficient technology available by using labor and energy resources. The company is the first cold storage company in Indonesia that uses the Automated Storage/Retrieval System (AS/RS) in its warehouse system.

The company has implemented global food safety and production standards and had set up its own production management system, modified from other systems. For example, it evaluated the Indonesian manual production system against the Chinese, Thai and Vietnamese systems, and combined them with European automated systems to improve production speed.

Visits abroad, online research and interaction with technology suppliers are major resources for the firm in exploring business opportunities, upgrading the production process, introducing product diversification, and improving its managerial capability. Product diversification and creating new markets are strategies for minimizing risk from any tuna supply instability.

\section{c. Role of entrepreneurs in technology upgrading}

The director has a long experience in working in the fishery industry and foreign shipping companies, and has developed effective networks in government and business both domestically and overseas. These have helped him to identify business opportunities, such as those in the goal of becoming the biggest salmon importer in Indonesia for the export market. To survive in the uncertainty of recent years, the director had the idea to diversify the business in terms of fish variety, produce new products, and transform the business from a processing company into a logistical service company.

\section{Company B}

\section{a. Company's business evolution}

Company B is one of the leading processed and export seafood companies in Indonesia, established in 1994 and located in Gresik, East Java. The company has grown very rapidly from only 15 workers in 1994 to nearly 14,000 workers in 2014, including 300 staff with university qualifications. The company has a production capacity of 55,000 tons per year from 45 plants, including mini-plants. The firm produces a variety of fish products, mostly frozen fish and processed products, such as cephalopods (36\%), surimi (27\%), frozen shrimp (13\%), fish balls $(13 \%)$, and ready-to-eat products $(11 \%)$.

The company was born envisioned as a global market player and a very expansive company. It grew from a small export company supplying the Japanese market specializing in dried anchovies, expanded into a seafood manufacturer, and has now evolved into an integrated seafood company. The key was to build a strong network of relationships with the buyers from local and international markets and sharing knowledge with local suppliers. Currently, 500 suppliers are working with the company, an increase from only two suppliers in 1994.

Some of Company B's plants were an investment by the local suppliers and some by Company $\mathrm{B}$ itself. The suppliers deliver fish directly to the 
nearest mini-plant for semi-processing and then they are transported as products to the central plant. The company assigns staff to help the local suppliers run the mini-plants according to standard. This is the company's way of keeping a fresh product supply chain and creating job opportunities in rural areas, as well as reducing the labor operating cost.

\section{b. Technological capability upgrading}

Market or buyer information is the main source of knowledge for the company in upgrading its technological capability, followed by information from the marketing unit, exhibitions and technology suppliers. The international buyers share information with the company - not only about required product types and standard requirements, but also regarding the evaluation and supervision of its production practices to comply with their standards. Involvement with global retailers, such as Carrefour and Walmart, is another driving factor for a firm to innovate. The global retail chains set the highest international standard for their suppliers. Competitors are another source of knowledge in driving company innovation. Buying technology, both from overseas and domestic, was a strategy to upgrade production capability. The technology was combined and modified to suit their needs. Despite the fact that its production capability is improving, conventional technology is still implemented, for example sun drying and manual production. Reasons for this are that some consumers prefer to consume products processed by traditional techniques, small suppliers cannot afford the technology practices and some production stages are better handled manually instead of by machine, e.g. peeling skin off shrimps.

The owner established his own managerial system by modifying foreign management systems and promoting teamwork. The management was characterized by: specialization, as each division manages a product; decentralization of production and supervision of suppliers to run the mini-plants; and a dedicated marketing unit for each export region. The company also has an $\mathrm{R} \& \mathrm{D}$ team working to update the operation with the latest seafood industrial news and issues. The company's R\&D unit conducts experimental test- ing that helps the company to constantly improve quality and value-added seafood products. The company provides continual training in capability upgrading for all its employees and local suppliers.

\section{c. Role of the entrepreneur for technology upgrading}

The entrepreneur has a good relationship with international buyers and the company staff are his trusted partners as a global player. His role in upgrading the technological capacity include learning from best practice (international businesses) and combining these lessons with the local culture. In order to achieve his vision, the owner invites his staff to join him on visits abroad to observe how the seafood industry in other countries operates and thus strengthened his relationships with local suppliers.

The entrepreneur plays a significant role in resolving seasonal supply of raw materials through supporting product diversification and combining unique products and unique business processes at all times. He brings ideas for new products into the tangible business.

\section{Company $\mathrm{C}$}

\section{a. Company's business evolution}

Company $\mathrm{C}$ is a seafood processing company located in a marine industrial complex near Jakarta's main port and is one of the five largest companies in this area. The current production capacity is approximately 13-15 containers per month for several fish products, with the majority for export markets. Europe is the biggest market for the company. All exported products are processed by the company, except for tuna, which is exported to Vietnam. The company has a policy limiting sales of fresh fish to avoid the potential loss of added-value by processing.

The company's owner began the business as a ship owner in the 1990 s, evolving into a fish trading company in 2004. Experience from fish trading brought the company capability to process fish products for export markets, and thus Company C was established in 2009. 
As a former ship owner, the owner of Company $\mathrm{C}$ has an advantageous knowledge of the ship operating business, even for fish catching. The company has a fish cold storage facility in Bali to maintain product quality and then transports the products to Jakarta for further processing. The status of fish supply influenced the firm's decision whether to make a contract or not with the ship owners or the fish suppliers.

\section{b. Technological capability upgrading}

The source of innovation, especially product innovation, is primarily from the market and international standard requirements, such as North American, European and Asian standards. Like its competitors, Company $\mathrm{C}$ also produces various products, but it is more capable to follow global market trends and standards. The firm obtains and manages feedback from customers in two ways: by sending samples of new products to customers, or by accepting the customer's required specifications on custom-order products. The company also maintains a punctual delivery service for customers, especially for its regular customers.

To upgrade its production capability, the company needed to import technology as local technology was not sufficiently developed. The technology suppliers provided training for the employees and an after-sales service. The company's capacity to maintain the quality of their products is embedded in the quality of the human resources as well as the required equipment and technology quality control (QC). Thus, the company conducts training, weekly briefings, and has adopted standard practices to improve employees' understanding about the quality standards.

The company's ability to compete in global markets also depends on the company's logistical capacity, supported by its own cold storage facilities in Jakarta and Bali and expanded by a larger factory in Jakarta's marine industrial complex. The company has plans not to expand into yet another added-value related industry such as fish canning in the near future, as it will focus on increasing production capacity.

\section{c. Role of the entrepreneur for technology upgrading}

The owner of the company has played a significant role in building the company into one of the five largest seafood processing enterprises in Jakarta's marine industrial complex. He has acquired knowledge continually and upgraded his entrepreneurial skills through a learning process. He started his business as a ship owner and shifted it to become a processing company, directly setting the global market as the main business target.

One of his important entrepreneurial skills is managing the risk of supply instability. He applies logistics management, storing fish in cold storage facilities during periods of oversupply and selling it for future demand as the market rises.

He maintains a good relationship with both the ship owners and his staff. During the outseason, the ship owners in return prioritize the supply of fish to Company C. The company's owner also maintains good relationships within the company by always emphasizing equality between him and the employees. This status has motivated the employees to work productively within a conducive environment.

\section{MODES OF INNOVATION AND THE INNOVATIVE ENTREPRENEUR IN FISH PROCESSING COMPANIES}

This section discusses the comparison among the findings in the three cases. The discussion focuses on three aspects: (i) modes of innovation and the enabling factors from the SIS perspective; (ii) characteristics of an innovative entrepreneur; and (iii) pathways toward export markets by a fish processing company.

\section{A. Modes of innovation and the enabling factors}

The three case studies have similarities in their respective innovation modes, as well as in the enabling factors from the SIS perspective. Indonesian fish processing companies apply several innovation modes, such as market/user-dominated innovation, cost cutting-oriented innovation, 
business innovation, and management innovation. Each mode of innovation has a variety of innovation activities (see Table 1).

\section{a. Market/user-dominated innovation}

Market/user-dominated innovation is a generic mode of innovation in fish processing companies. Most product development and diversification in Indonesian fish processing companies is based on information feedback from users that encourages a company to engage in continual improvement. The companies develop their own brands to support their market position and differentiation in the world market. The companies have to meet particular standard certifications to guarantee their customers the quality and safety of the products, according to both national and international standards. Users can be involved in product development and diversification directly or indirectly. The users' direct involvement is achieved by product testing. The users' indirect involvement is achieved by collecting market information through interaction with wholesalers, global retailers, the marketing department, or by his own/entrepreneurial observation.
The enabling factors of any market/userdominated innovation come from the actors, market, technology and institutional factors. There are internal and external actors involved. The external actors consist of global retailers, foreign buyers, and fish processing machinery contractors, while the internal actors include marketing and R\&D staff within the company. The companies obtained knowledge for establishing new product development by interacting with their international buyers through the director, marketing staff and R\&D staff. The market trends influenced the companies to evaluate the products continually. The use of modern technology has made the companies more dynamic in responding to the users' needs, such as food storage and processing support, as well as logistical technology support. To comply with the users' needs and international standards, the companies normally have to improve their production technology.

\section{b. Cost-cutting oriented innovation}

Cost-cutting innovation is mostly related to the internal production process. Cost inefficiency

Table 1.

Enabling factors for innovation

\begin{tabular}{|c|c|c|c|c|c|}
\hline \multirow{2}{*}{$\begin{array}{c}\text { Innovation } \\
\text { modes }\end{array}$} & \multicolumn{4}{|c|}{ Variety of innovations activities } & \multirow{2}{*}{$\begin{array}{l}\text { SIS enabling factors } \\
\text { (Actor, Network, } \\
\text { Market, Institution, } \\
\text { Technology) }\end{array}$} \\
\hline & A & B & C & $\begin{array}{l}\text { Similarities and } \\
\text { differences }\end{array}$ & \\
\hline $\begin{array}{l}\text { Market/user } \\
\text { dominated } \\
\text { innovation }\end{array}$ & $\begin{array}{l}\text { Product diversification } \\
\text { Own brand } \\
\text { Added value products } \\
\\
\text { Product quality with } \\
\text { international standard }\end{array}$ & $\begin{array}{l}\text { Product differentiation } \\
\text { Own brand } \\
\text { Added value products and } \\
\text { new product (unique) in } \\
\text { market } \\
\text { Product quality with } \\
\text { international standard }\end{array}$ & $\begin{array}{l}\text { Product diversification } \\
\text { Own brand } \\
\text { New product from user } \\
\text { order } \\
\text { Product quality with } \\
\text { international standard }\end{array}$ & $\begin{array}{l}\text { Product diversification } \\
\text { Own brand } \\
\text { Added value products. } \\
\text { Unique products } \\
\text { Product quality with } \\
\text { international standard }\end{array}$ & $\begin{array}{l}\text { Global retailers, foreign buyers. } \\
\text { Market trend/determination } \\
\text { Processing technology and } \\
\text { logsitics technology supports } \\
\text { National and International } \\
\text { Standard certification }\end{array}$ \\
\hline $\begin{array}{l}\text { Cost } \\
\text { cutting } \\
\text { oriented } \\
\text { innovation }\end{array}$ & $\begin{array}{l}\text { Raw material sources } \\
\text { diversification } \\
\text { Import raw material and } \\
\text { interlock collaboration } \\
\text { Automated storage } \\
\text { system or IT system }\end{array}$ & $\begin{array}{l}\begin{array}{l}\text { Raw material sources } \\
\text { diversification }\end{array} \\
\text { Imported raw material } \\
\text {-Logistics in various } \\
\text { locations } \\
\text {-Decentralisation in } \\
\text { purchasing and production }\end{array}$ & $\begin{array}{l}\text { High price of supply } \\
\text { reduced by by storege } \\
\text { capacity } \\
\text { - } \\
\text { Storage capacity } \\
\text { expansion }\end{array}$ & $\begin{array}{l}\text { Reduce uncertainty and } \\
\text { cost of raw material } \\
\text { supply } \\
\text { Reduce cost by import } \\
\text { Reduce cost of } \\
\text { transportation, logistics } \\
\text { and overhead cost }\end{array}$ & $\begin{array}{l}\text { Market competition and foreign } \\
\text { Supplier network } \\
\text { Market information updating, } \\
\text { bus iness network, and } \\
\text { International experts }\end{array}$ \\
\hline $\begin{array}{l}\text { Business } \\
\text { Innovation }\end{array}$ & $\begin{array}{l}\text { Business Innovation (in } \\
\text { food logistics) } \\
\text { Aquaculture business, } \\
\text { market diversification } \\
\text { (domestic and export) }\end{array}$ & $\begin{array}{l}\text { Regional based Production } \\
\text { line } \\
\text { Market diversification } \\
\text { (domestic and market) }\end{array}$ & $\begin{array}{l}\text { Market information } \\
\text { system/User testing } \\
\text { system }\end{array}$ & $\begin{array}{l}\text { Vary between companies } \\
\text { Market diversification } \\
\text { and/or information }\end{array}$ & $\begin{array}{l}\text { Technology and raw material } \\
\text { uncertainty from local supplier } \\
\text { Business network, funding } \\
\text { support }\end{array}$ \\
\hline $\begin{array}{l}\text { Managerial } \\
\text { innovation }\end{array}$ & $\begin{array}{l}\begin{array}{l}\text { Inter-lock collaboration } \\
\text { (lose relationship) }\end{array} \\
\begin{array}{l}\text { Automated cold } \\
\text { storage system and } \\
\text { fish transhipment } \\
\text { system }\end{array} \\
\begin{array}{l}\text { Total logistics solution } \\
\text { for exellent delivery } \\
\text { service }\end{array} \\
\end{array}$ & $\begin{array}{l}\text { Supply chain management } \\
\text { (tight relations hip with } \\
\text { suppliers) } \\
\text { Build some mini plants } \\
\text { closely located to the } \\
\text { source of material } \\
\text { Customer priority service } \\
\text { with discounted price }\end{array}$ & $\begin{array}{l}\text { Supply chain } \\
\text { management (through } \\
\text { suppliers) } \\
\text { Cold storages and } \\
\text { processing units in two } \\
\text { locations }\end{array}$ & $\begin{array}{l}\text { Manage partnerships } \\
\text { with suppliers (supply } \\
\text { chain management) } \\
\text { Buildig large capacity of } \\
\text { storage and processing. } \\
\text { Automated stroge } \\
\text { system } \\
\text { Customer is busines } \\
\text { assets }\end{array}$ & $\begin{array}{l}\text { Business network, technology } \\
\text { supplier, skilled production } \\
\text { staff } \\
\text { Market competition, logistic } \\
\text { services and technology. }\end{array}$ \\
\hline
\end{tabular}


occurs due to the seasonal supply of raw material available for the processing centers, high-risk transportation modes - particularly from suppliers to processing centers - and increasing labor costs. The three companies have implemented efficient production management (such as raw material diversification), used imported raw materials, established the plants near the raw material sources, and adopted logistical automation. Market factors (competition), technology (ICT access and logistical technology) and networks (raw material supply chains) are the enabling factors for cost-cutting innovation.

The Indonesian fish processing industry is marked by intense competition for securing raw material supplies for the processing centers. Innovation in logistics such as cold storage, automated storage, advanced processing and packaging and cold supply chains has reduced the cost of logistical and raw material processing. Another way to reduce production costs is by establishing closer networks with local and international suppliers, or even with competitors or international seafood business companies.

\section{c. Business innovation}

Each company has developed new businesses when the existing business could not be fully operated. For example, Company A had difficulties in maintaining the supply of raw material, hence the company decided to shift a part of its business to become a food logistical service for other products instead of only seafood. Company B established a specific production line for each export region to minimize the problems associated with mixed standards and traceability of products. Company $\mathrm{C}$ adopted a strategy to expand its storage capacity so that they are not bothered by a fluctuating supply of raw material. The enabling SIS factors that contributed to business innovation were technology, institutions, actors, and networks. The advanced logistical technology became easier to access when supported by funding institutions. The strong business networks created opportunities for fish processing companies to learn about new production processes. The uncertainty of raw material supplies from local sources motivated them to diversify their respective businesses.

\section{d. Managerial innovation}

Managerial innovation includes marketing, logistical and service innovations. Marketing innovations were achieved through managing partnerships along the fish commodity supply chains. Intense competition between fish processing companies drove the fish processing companies to work more closely with suppliers through supply chain management or through interlocking collaboration under a loose relationship. Managing good partnerships is an important strategy for any company to ensure its partners are committed to supply them continuously. The companies maintaned these partnerships by providing ice supply and training about production quality for the fish suppliers. The more intense the companies' relationships, the more committed the suppliers became to work with them.

For logistical innovations the three companies reduced seasonal supply risks and ensured better quality by expanding and/or applying more advanced technology. The available business and governmental networks contributed to the companies' systems to improve their logistical technology. The other driver was information availability from technology suppliers about new technology. Other service innovations by fish processing companies include adopting innovations that offer more services to their customers. The delivery service was possible since logistical technology was available. The demand for logistical technology was also high due to market competition that had reduced the production capacity of some companies.

\section{B. Characteristics of innovative entrepreneurs}

An entrepreneur's characteristics are embedded in every company's owner and/or president/director. The characteristics of an innovative entrepreneur are articulated through developing entrepreneurial skills and networks, implementing the business vision, exploring new opportunities, and adopting creative problem-solving. The following section explains the similarities and differences of 
entrepreneurial characteristics when implementing business innovations (see Table 2).

\section{a. Developing entrepreneurial skills}

Entrepreneurial skills are acquired through a gradual process. The process of acquiring entrepreneurial skills for Companies A and B was supported by formal education in the general fishery industry that was a useful modality to enter the fish processing business wirh. For Company C, entrepreneurial skill was primarily obtained from family and neighborhood experience. This was also the case for the owner of Company B.

For developing entrepreneurial skills, the three companies had run other business lines before establishing their own fish processing company. Companies A and B had the same initial business, which was fish trading; Company B ran a business that directly exported its products to foreign markets, while the owner of Company A established his products for the domestic market. From the beginning, the owner of Company B showed a strong entrepreneurial skill in accessing unconventional seafood markets in Japan by exporting small anchovy. The owner of Company $\mathrm{C}$ was a ship owner before starting as a fish trader. His first business was to supply fish to national processing companies or traders before entering the business of fish processing.

\section{b. Developing entrepreneurial networks}

The three companies' owners developed similar entrepreneurial networks in order to be able to compete in the global market. The three companies' owners have maintained their business networks nationally and internationally. To expand

Table 2.

Characteristics of innovative entreprenuer

\begin{tabular}{|c|c|c|c|}
\hline \multirow{2}{*}{$\begin{array}{l}\text { INNOVATIVE } \\
\text { ENTREPRENEUR }\end{array}$} & \multicolumn{3}{|c|}{ INNOVATION ACTIVITIES } \\
\hline & Company A & Company B & Company C \\
\hline $\begin{array}{l}\text { Developing } \\
\text { entrepreneural } \\
\text { skill }\end{array}$ & $\begin{array}{l}\text { - Bachelor in fishery } \\
\text { - Develop business } \\
\text { from fish trader } \\
\text { - Chairman of fishery } \\
\text { association }\end{array}$ & $\begin{array}{l}\text { - Bachelor in fishery } \\
\text { - Develop business } \\
\text { from fish trader } \\
\text { - Coming from fish } \\
\text { trader family }\end{array}$ & $\begin{array}{l}\text { - Bachelor in fishery } \\
\text { - Develop business } \\
\text { from fish vessel } \\
\text { owner } \\
\text { - Coming from } \\
\text { fishermen family }\end{array}$ \\
\hline $\begin{array}{l}\text { Building } \\
\text { Entrepreneural } \\
\text { network }\end{array}$ & $\begin{array}{l}\text { - Relationship with } \\
\text { local and } \\
\text { international } \\
\text { seafood business } \\
\text { players as well as } \\
\text { local and foreign } \\
\text { government } \\
\text { agencies }\end{array}$ & $\begin{array}{l}\text { Work closely with } \\
\text { network of } \\
\text { suppliers and } \\
\text { foreign buyers }\end{array}$ & $\begin{array}{l}\text { - Relationship with } \\
\text { suppliers (vessels) } \\
\text { and foreign buyers }\end{array}$ \\
\hline $\begin{array}{l}\text { Tmplementing } \\
\text { business vision }\end{array}$ & $\begin{array}{l}\text { - Acquiring high } \\
\text { technology } \\
\text { equipment to } \\
\text { produces standard } \\
\text { products, and } \\
\text { updating staff } \\
\text { knowledge by } \\
\text { regular in-house } \\
\text { training }\end{array}$ & $\begin{array}{l}\text { - Creating } \\
\text { competitive and } \\
\text { added value } \\
\text { products and } \\
\text { realizing it by } \\
\text { various staff } \\
\text { development } \\
\text { program }\end{array}$ & $\begin{array}{l}\text { - Maintaing } \\
\text { international } \\
\text { standard products, } \\
\text { and updating staff } \\
\text { knowledge by } \\
\text { regular in-house } \\
\text { training }\end{array}$ \\
\hline $\begin{array}{l}\text { Exploring new } \\
\text { opportunity }\end{array}$ & $\begin{array}{l}\text { - Accessing } \\
\text { international } \\
\text { information (e.g. } \\
\text { salmon processing } \\
\text { imported from } \\
\text { Norway) }\end{array}$ & $\begin{array}{l}\text { - Creating new } \\
\text { market (e.g. red } \\
\text { snapper in US } \\
\text { market and } \\
\text { takoyaki in Japan } \\
\text { market) }\end{array}$ & $\begin{array}{l}\text { - Creating new } \\
\text { products } \\
\text { demanded by } \\
\text { market }\end{array}$ \\
\hline $\begin{array}{l}\text { Creative problem } \\
\text { solving }\end{array}$ & $\begin{array}{l}\text { - Diversifying fish } \\
\text { commodities, } \\
\text { producing new } \\
\text { products, } \\
\text { expanding market } \\
\text { - Utilizing its modern } \\
\text { cold storage for } \\
\text { other purposes such } \\
\text { as storage for beef, } \\
\text { potatoes and } \\
\text { cheese. }\end{array}$ & $\begin{array}{l}\text { - Diversifying fish } \\
\text { products, supply of } \\
\text { raw materials and } \\
\text { markets } \\
\text { - Building } \\
\text { processing units } \\
\text { (near the local } \\
\text { suppliers) for one } \\
\text { product and special } \\
\text { market. } \\
\text { - Introducing new } \\
\text { added value } \\
\text { products in market. }\end{array}$ & $\begin{array}{l}\text { - Maintaining the } \\
\text { trust of suppliers } \\
\text { - Building large } \\
\text { capacity }\end{array}$ \\
\hline
\end{tabular}


the number of business partners, Company A developed a good relationship with a foreign government (Norway) to facilitate its partnership with a foreign company. The three companies built trust using two-way communication as the key to sustain the network, taking advantage of business opportunities and overcoming any business uncertainty.

\section{c. Implementing the business vision}

The three companies implemented their business visions to become global market players by leveraging their respective capabilities for storage, processing, and exploring international markets. Companies built the capability to implement their global vision through capacity building of the staff. Company A has a similarity with Company $\mathrm{C}$ by doing in-house formal training for their staff as the preferred way to equip them with the required skills. The improvement of staff capacity in technological matters is mostly through training supervised by technology and machinery distributors. Company B used a different approach by involving its staff in field visits in foreign fishery companies. Another unique factor is using local knowledge (e.g. fish catching techniques, etc.) to teach other staff using a different culture. For Company A, leveraging its good relationship with Norway's government brought the company the opportunity to become a salmon importer from Norway. The success of Company A was in following this business opportunity through the process of identifying the opportunity, acquiring suitable new technology and taking advantage of supporting governmental networks.

\section{d. Exploring new opportunities}

When exploring new opportunities, Company B showed more courage in creating new products not existing in the target market, such as red snapper for the US market and tokoyaki for the Japanese market. The owner influenced change in the markets gradually through continual effort. He patiently assured his potential buyers that the new products will be delivered regularly, comply with the required quality and will satisfy the market taste. The combination of market networks (customers) and individual capability (to learn and see what others do not) has allowed the owner of Company B grasp the business opportunities boldly.

Compared to Companies A and B, Company $\mathrm{C}$ tends to focus on complying with market requirements, particularly regarding the quality, quantity, and punctuality of deliveries to the customers. Creating new products, as in the case of Company B, or importing foreign products for export, as in the case of Company A, are not the main concerns of Company C. Instead, the company emphasizes more on responding to the standards of customer demand, where fish products are mostly decided by the standards of customer demand in the global market.

\section{e. Creative problem-solving}

In order to be competitive the owner of any company has to become a creative problem-solver. Company A acquired automated technology to comply with international standards and speed up the production process. Company B achieved product differentiation to make its products more competitive, while Company $\mathrm{C}$ complied with international standards for its existing products with less differentiation. The owner of Company A, who is influenced by a background in a fishery academy, used more sophisticated technology for producing standard-compliant products, while the owner of Company B, also influenced by a tertiary background in fishery, saw that new markets could be created by introducing new products. The owner of Company $\mathrm{C}$ tended to play more safely by creating products which had already existed in the market.

The ways of dealing with the problem of seasonal fish supply vary among the companies. Company A emphasized the combination of human skill and technology to speed up the production process. The company invested in an integrated and computer-based logistical system to overcome supply uncertainty. Furthermore, the infrastructure became another business opportunity for Company A to produce derivative products, expanding from fish processing into fish importing-exporting and integrated logistics. 
Company B created a continuous supply chain by developing supply networks from several of its processing units operating during the whole year. One processing unit only produces one product for any particular market. The network of local processing units has built a trust-based relationship, in addition to the company equipping them with sufficient knowledge and capacity. The company created added value by producing fish balls and built a supporting company to supply the raw material (surimi).

Company C's main concern about fish supply was building sufficient cold storage facilities to deal with supply uncertainty. Company C identified trust as the key element (besides the logistics system) in sustaining fish supply by local ships. This spirit was transmitted by the owner to his staff by applying an egalitarian leadership style, even though the company has no derivative product from its logistical system, a less complicated product differentiation and a less sophisticated production network compared to Companies A and B.

\section{Entrepreneurial network and pathways toward export markets}

The three companies started their business in a similar period, the 1990s, with different stories and performances. A successful leading company as a global market player is driven by the entrepreneur's clear orientation in terms of creativesegmentation towards the market niche by creating innovative new products for the market. The leading companies generally become successful global market players because the entrepreneur has specific capabilities, i.e. the entrepreneurial network built by company founders has become a dominant characteristic of innovative entrepreneurs in leading the Indonesian fish processing companies.

The entrepreneurial networks exist and work in global distribution chains that are widely adopted by companies to export their products through buyer-producer relationships. The buyer-producer relationships induce user-dominated innovation, through which the producers gain knowledge about the patterns of buyer demand, product quality standards, and the processing technology needed to produce the required product.

From the view point of the learning process, Company A is a fastly learned global. The company started as a domestic trader and develop quickly. In a very short time since its establishment (t1, Figure 2) the company achieved the capacity to switch from a domestic trader into a producer for export markets. This was followed by rapid development as a producer for export markets, then the company quickly shifted toward a mature level as indicated by the capacity to pursue further growth more slowly. Company B is a global born directly. The company was born directly as a trader for export markets. From a trader, it shifted to become a producer for export markets with the ability to learn normally with fewer surprises and slowdowns as other global market players. It reached the capacity to achieve rapid growth as a producer for export markets in an average period of time ( $\mathrm{t} 2$, Figure 2). This average growth represents its time as a trader for export markets at the beginning, followed by rapid development as a producer for export markets. Currently, the company is pursuing further growth. Company $\mathrm{C}$ is a delay learned global company. The company had the ability to learn gradually as a domestic trader, resulting in a long delay ( $\mathrm{t} 3$, Figure 2) in achieving the capacity to switch from a domestic trader into a producer for export markets. The company experienced a steady but slower growth as a domestic trader over a longer time. Upon achieving sufficient capacity and favorable conditions the company followed a sudden shift to become a producer for export markets with fast growth. Currently, the company is growing significantly in its pursuit of further development (see Figure 2). The pathways toward export markets by fish processing companies can be categorized as: global born directly, fastly learned global, and delay learned global companies. These categories support the relevant Mets category (2012).

\section{Lessons learned}

In order to meet the increasing demand for product quality by global distribution networks, the companies need to improve both product 


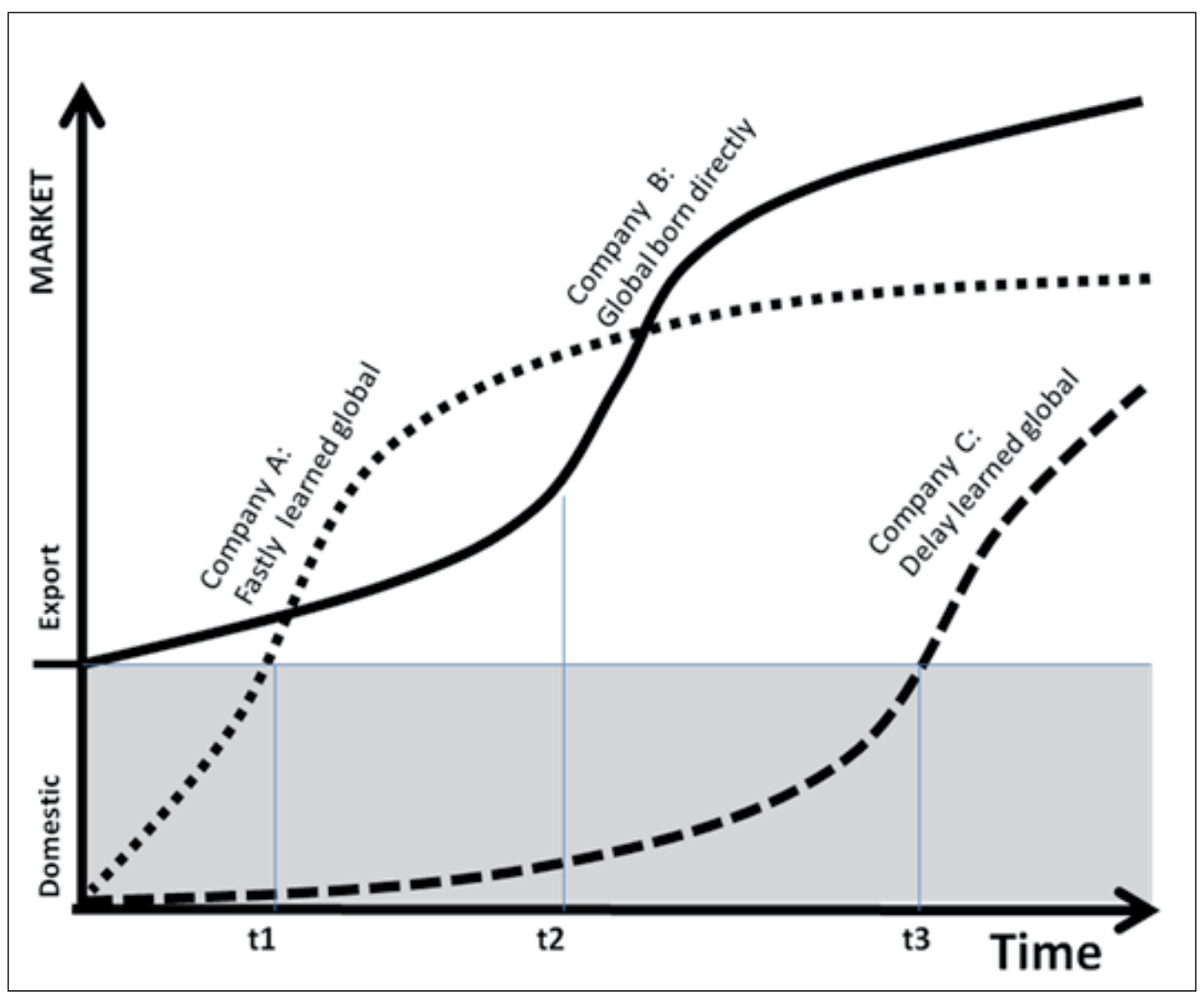

Source: constructed by authors

Figure 2. Pathways toward export market

and process technology. The government should facilitate the companies' interactions with local universities or other STI centers to increase technological capability of the companies to meet the demand for higher added-value products.

Furthermore, institutional support has an important role in facilitating fish processing companies in their pursuit of improvement in the quality of products, expansion of markets overseas, and joining of global distribution networks. The government should encourage domestic companies to improve competitiveness through trade policies and various schemes to promote innovation which: (i) facilitate equipment procurement for capacity enhancement and quality improvement; (ii) support access to export markets and search for suitable markets to meet the needs of overseas buyers; and (iii) lower the cost of production and trading as well as create a conducive business environment that will spur the competitiveness of domestic companies and help their evolution into global market players.

\section{CONCLUSION}

Based on the cross-case analysis, we draw some important conclusions.

Firstly, technological capability upgrading and innovation activities has taken place in the fish processing companies in Indonesia as follows:

1. The main characteristic of fish processing companies is less interaction with local universities or other STI (science, technology and innovation) centers, and innovation is mainly done through learning by DUI (doing, using and interacting);

2. Fish processing companies are generally characterized as low-tech industries which are labor-intensive, with a general specifica- 
tion of products, and food safety standard products.

3. The companies mostly apply adaptive innovation, modified from existing technology or knowledge, except for the leading companies that apply innovation for new products in the market. Therefore, the modes of innovation in the Indonesian fish processing companies are generally: user-dominated innovation, cost-cutting oriented innovation, business innovation, and managerial innovation.

4. Actors, technology, markets and networks are the main enabling factors for innovation in the Indonesian fish processing companies. Building human resource capability in the fish processing companies applies a similar approach to training supervised by technology suppliers, considering their technology is imported.

Secondly, an innovative entrepreneur performs a variety of innovative activities: developing entrepreneurial skills and networks, implementing the global vision, exploring new opportunities, and adopting creative problemsolving. The development of entrepreneurial networks is a dominant characteristic of innovative entrepreneurs in leading the Indonesian fish processing companies.

Thirdly, the entrepreneurial networks exist and work in global distribution chains that are widely adopted by companies to export their products through buyer-producer relationships. The buyer-producer relationships induce user-dominated innovation, through which the producers gain knowledge about the patterns of buyer demand, product quality standards and the processing technology needed to produce the required product.

Fourthly, the study has found that the pathways toward export markets by global-oriented fish processing companies can be categorized as: global born directly, fastly learned global, and delay learned global companies. These categories support the Mets (2012) categorization, namely: global born, learned global and born again global companies. The main drive behind entrepreneurs' ability to transform companies into global market players is due to the entrepreneurs' specific capabilities, i.e. the founders of the companies are alert to new international market opportunities because of the knowledge and/or learning acquired from earlier business activities.

\section{ACKNOWLEDGEMENTS}

The authors are indebted to Prof. Patarapong Intarakumnerd, Prof. Fukunari Kimura, Dr. Machikita Tomohiro and Dr. Yasushi Ueki for their valuable comments and enrichments on this research paper. This work was supported by IDE ERIA/ IDE-JETRO Study Project 2013 on Entrepreneurship and Local Technological Capacity in the East Asian Natural Resource-Based Production Networks, for which the authors extend many thanks.

\section{REFERENCES}

Aslesen, G. W. (1999). Governance and the innovation system of the fish-processing industry in Northern Norway. The STEP Report Series, No R-07, 7-17.

Asmara, J. (2012). Penguatan zona ekonomi ekslusif dalam pengelolaan sumber daya maritim Indonesia di wilayah perbatasan [Strengthening the exclusive economic zone in managing Indonesian marine resource at areas of the sea border]. Jurnal Sosial Ekonomik Kelautan dan Perikanan, 2(2), 131-144.

Van Duijn, A. P., Beukers, R., \& van der Pijl, W. (2012). The Indonesian seafood sector: $A$ value chain analysis (pp. 46-56). Netherlands: Centre for the Promotion of Imports, Ministry of Foreign Affairs.

Giusta, M. D. (2010). Entrepreneurial networks as social capital. In M. Casson (Ed.), Entrepreneurship theory, networks, history (p. 150). Cheltenham: Edward Elgar.

González-López, M. (2012). The Spanish cod fishing industry: Radical production changes without significant changes in the innovation system. Journal of Entrepreneurship, Management and Innovation (JEMI), 8(4), 35-51.

Jeffs, A. (n.d.) Development of innovation capabilities in the New Zealand seafood industry sector. Auckland: National Institute of Water and Atmospheric Research. 
Juarno, O., Oktaviani, R., Fauzi, A., \& Nuryartono, N. (2011). Kinerja produktivitas dan faktor yang berpengaruh terhadap total factor productivity (TFP) tambak udang Indonesia [Productivity performance and the factors of TFP on shrimp aquaculture in Indonesia]. Jurnal Sosial Ekonomik Kelautan dan Perikanan, 6(2), 149-168.

Malerba, F. (Ed.). (2004). Sectoral system innovation: Concepts, issues and analysis of six major sectors Europe (pp. 9-35). Cambridge: Cambridge University Press. http://dx.doi.org/10.1017/ CBO9780511493270

Malerba, F., \& Sunil, M. (Eds.). (2009). Sectoral system innovation and production in developing countries: Actors, structure and evolution (pp. 3-22). Cheltenham: Edward Elgar. http:// dx.doi.org/10.4337/9781849802185

Mets, T. (2012). Creative business model innovation for globalizing SMEs. In T. Burger-Helmchen (Ed.), Entrepreneurship-creativity and innovative business models (pp. 169-187). Rijeka Croatia: Intech. http://dx.doi.org/10.5772/37915

Nicita A., Ognivtsev, V., \& Shirotori, M. (2013). Global supply chains: Trade and economic policies for developing countries (pp. 1-3). Geneva: UNCTAD (Study Series No. 55).
Saptanto, S. (2011). Daya saing ekspor produk perikanan Indonesia di lingkup asean dan AseanChina [Export competitiveness of Indonesian fishery products in Asean and China]. Jurnal Sosial Ekonomi Kelautan dan Perikanan, 6(1), 51-60.

Sunoko, R., \& Huang, H. (2014). Indonesia tuna fisheries development and future strategy. Marine Policy, (43), 174-183. http://dx.doi. org/10.1016/j.marpol.2013.05.011

Vallejo, N., Hauselmann, P., \& Asante, R. (2009). The role of supply chains in addressing the global seafood crisis. United Nations Environment Programme (UNEP) Report.

Weerawardena, J., Mort, G.S., Liesch, P.W. \& Knight, G. (2007). Conceptualizing accelerated internationalization in the born global company: A dynamic capabilities perspective. Journal of World Business, (42), 301. http://dx.doi. org/10.1016/j.jwb.2007.04.004

Widodo, K. H., Perdana, Y. R., \& Sumardjito, J. (2011). Product-relationship-matrix concept for marine and fishery supply chain model development. Jurnal Teknologi Pertanian, 12(2), 122-129.

Zucchella A. \& P. Scabini. (2007). International entrepreneurship theoretical foundations and practices (pp. 128, 129, 133). New York: Palgrave Macmillan. 